\title{
Improving the Keeping Quality and Vase Life of Cut Alstroemeria Flowers by Pre and Post-harvest Salicylic Acid Treatments
}

\author{
Elnaz SOLEIMANY-FARD ${ }^{1 *}$, Khodayar HEMMATI², Ahmad KHALIGHI' \\ ${ }^{1}$ Department of Horticulture Sciences, Science and Research Branch, Islamic Azad University, \\ Tehran,Iran; Elnazsoleimany@gmail.com (*correspondingauthor) \\ ${ }^{2}$ Department of Horticulture Sciences, Gorgan University of Agricultural Sciences and Natural Resources, Gorgan, Iran
}

\begin{abstract}
Keeping quality and length of vase life are important factors for evaluation of cut flowers quality, for both domestic and export markets. Studding the effect of pre- and post-harvest salicylic acid applications on keeping quality and vase life of cut alstroemeria flowers during vase period is the approach taken. Aqueous solutions of salicylic acid at 0.0 (with distilled water), 1, 2 and $3 \mathrm{mM}$ were sprayed to run-off (approximately $500 \mathrm{~mL}$ per plant), about two weeks before flowers harvest. The cut flowers were harvested in the early morning and both of cut flowers treated (sprayed) and untreated were kept in vase solutions containing salicylic acid at 0.0 (with distilled water), 1, 2 and $3 \mathrm{mM}$. Sucrose at 4\% was added to all treatments as a base solution. The changes in relative fresh weight, water uptake, water loss, water balance, total chlorophyll content and vase life were estimated during vase period. The results showed that the relative fresh weight, water uptake, water balance, total chlorophyll content and vase life decreased significantly while the water loss increased significantly during experiment for all treatments. A significant difference between salicylic acid and control treatments in all measured parameters is observed. During vase period, the salicylic acid treatments maintained significantly a more favourable relative fresh weight, water uptake, water balance, total chlorophyll content and supressed significantly water loss, as compared to control treatment. Also, the results showed that the using salicylic acid increased significantly the vase life cut alstroemeria flowers, over control. The highest values of measured parameters were found when plants were treated by pre + post-harvest application of salicylic acid at $3 \mathrm{mM}$. The result revealed that the quality attributes and vase life of cut alstroemeria flowers were improved by the use of salicylic acid treatment.
\end{abstract}

Keywords: alstroemeria, properties, total chlorophyll, vase period, water relations

\section{Introduction}

Alstroemeria is a member of the Alstroemeriaceae family and is one of the very important in global cut flowers production. It is widely used as cut flowers because the flowers are available in numerous colours like yellow, orange, pink through scarlet to purple and violet (Norbaek et al., 1996). Leaf yellowing associated with early senescence is a major problem in alstroemeria, which may occur within a few days and proceeds very rapidly (Mutui et al., 2001). Senescence of cut flowers may depend on many factors such as; water stress (Sankat and Mujaffar, 1994), carbohydrate depletion, microorganisms (Witte and Van Doom, 1991) and ethylene effects (Wu et al., 1991; Da Silva, 2003).

Short postharvest vase life is one of the most important problems on the cut flowers. The maintenance of vase life is an important quality attribute in these economically significant cut flowers. A suitable method for vase life extension, which easy to use, natural, safe and inexpensive compounds is always crucial in this respect for large-scale applications. A number of strategies have been used to maintaining good quality and extending the vase life of cut alstroemeria flowers such as; treatments with silver thiosulphate (STS) (Nowak and Rudnicki, 1990), gibberellins (GA) and cytokinins (CK) (Hicklenton, 1991; Jordi et al., 1995; Mutui et al., 2003), accel (BA+GA $\left.{ }_{4+7}\right)$ (Mutui et al., 2001) and thidiazuron (TDZ) (Ferrante et al., 2002).

Recently, there is an increasing interest in the use of natural compounds for maintenance of cut flowers quality and extension of vase life. Salicylic acid (SA), a widely distributed compound in plants, belongs to a group of phenolic compounds. Salicylic acid could be considered as an endogenous plant growth regulator involved in the regulation of plant growth, development and disease resistance mechanisms (Hayat et al., 2010; Luo et al., 2011). Also, salicylic acid has been found to suppress ACC-oxidase activity that is the direct precursor of ethylene and decrease ROS (Reactive Oxygen Species) with increasing antioxidant enzyme activity (Ansari and Misra, 2007; Mba et al., 2007; Mahdavian et al., 2007; Canakci, 2008; Kalidage, 2009). Numerous authors have reported the application of salicylic acid at different concentration extended vase life in cut flowers of rose (Zamani et al., 2011), gerbera and lily (Kazemi et al., 2011 a and b), carnation (Kazemi and Ameri, 2012) and chrysanthemum (Vahdati et al., 2012). 
Salicylic acid treatment has the potential for maintenance of cut flowers quality and extension of vase life. However, little information exists on the use of salicylic acid on keeping quality and vase life improvement of cut alstroemeria flowers. Therefore, the objective of this research was to analyse and compare the effect of pre- and post-harvest salicylic acid applications on keeping quality and vase life of cut alstroemeria flowers during vase period.

\section{Materials and methods}

\section{Plant material and treatments}

Alstroemeria (cv. 'Tampa') flowers were obtained from local commercial greenhouses (Mashhad, Iran). Plants were grown in under standard greenhouse conditions with 22 and $16^{\circ} \mathrm{C}$ day and night temperatures, respectively. Solutions of salicylic acid at 0.0 (with distilled water), 1, 2 and $3 \mathrm{mM}$ were sprayed to run-off (approximately 500 $\mathrm{mL}$ per plant), about two weeks before flowers harvest. The cut flowers were harvested in the early morning and transported with appropriate cover (in plastic packages) immediately to laboratory. Then cut flowers were re-cut under water to $30 \mathrm{~cm}$ length. The both of cut flowers treated (sprayed) and untreated were placed in the glass vials $300 \mathrm{ml}$ solutions containing salicylic acid at 0.0 (with distilled water), 1, 2 and $3 \mathrm{mM}$. Sucrose at $4 \%$ was added to all treatments as a base solution. The flowers were kept in a controlled room at $19 \pm 2^{\circ} \mathrm{C}, 70 \pm 5 \%$ relative humidity and $12 \mu \mathrm{mol} \mathrm{m} \mathrm{m} \mathrm{s}^{-1}$ light intensity (cool-white fluorescence lamps) under a daily light period of $12 \mathrm{~h}$. The period from the first day ( 0 day) when cut flowers were placed in vase solutions, until they lost their ornamental value were investigation traits.

\section{Relative fresh weight, water uptake, water loss and water} balance

Relative fresh weight, water uptake, water loss and water balance were recorded 2 days intervals by measuring weights of vases without flowers and of flowers separately (He et al., 2006). Relative fresh weight of stems (flowers+leafy) was calculated as: relative fresh weight (\%) $=\left(\mathrm{W}_{\mathrm{r}} / \mathrm{W}_{\mathrm{t}-0}\right) \times 100$; where, $\mathrm{W}_{\mathrm{t}}$ is weight of stem $(\mathrm{g})$ at $t=$ days 0,2 , 4 , etc., and $\mathrm{W}_{\mathrm{t}-0}$ is weight of the same stem $(\mathrm{g})$ at $t=$ day 0 . Water uptake was calculated as: water uptake ( $\mathrm{g}$ stem $^{-1}$ day $\left.^{-1}\right)=\left(S_{t-1}-S_{t}\right)$; where, $S_{t}$ is weight of vase solution (g) at $t=$ days 0,2 , 4, etc., and $\mathrm{S}_{\mathrm{t}-1}$ tis weight of vase solution $(\mathrm{g})$ on the previous day. Water loss was calculated as: water loss $\left(\mathrm{g} \mathrm{stem}^{-1}\right.$ day $\left.^{-1}\right)=\left(\mathrm{C}_{\mathrm{t}-1}-\mathrm{C}_{\mathrm{r}}\right)$; where, $\mathrm{C}_{\mathrm{t}}$ is the combined weights of the cut stem and vase $(\mathrm{g})$ at $t=$ days $0,2,4$, etc., and $\mathrm{C}_{\mathrm{t}-1}$ is the combined weights of the stem and vase $(\mathrm{g})$ on the previous day. Water balance $\left(\mathrm{g} \mathrm{stem}^{-1}\right.$ $\left.\mathrm{day}^{-1}\right)$ was calculated as water uptake from the vase minus water loss from the stem.

\section{Total chlorophyll}

Total chlorophyll content was determined ( 2 days intervals) by chlorophyll meter (SPAD-502 Konica, Minolta, Tokyo), which is presented by SPAD values. Average of 3 measurements from different spots of a single leave was considered (Kazemi and Ameri, 2012).

Vase life

Vase life was assessed as the number days to wilting of flowers. The flowers were checked once a day for signs of deterioration.

\section{Experiment design and statistical analysis}

This experiment was conducted according to factorial based on completely randomized block design with 4 replicates and 3 samples (individual flowers) for each replication. Data were analyzed by Statistical Analysis System (SAS) software Version 9.1 using analysis of variance (ANOVA) and differences among means were determined for significance at $p<0.05$ using Tukey's test.

\section{Results and discussion}

\section{Relative fresh weight}

As shown in Fig. 1, relative fresh weight increased significantly during the first 4 days of experiment and from this time until end of the experiment decreased significantly. Similar patterns of changes were also reported for cut rose flowers (Lu et al., 2010; Alaey et al., 2011). A variation in terms of relative fresh weight was observed among the treatments and the differences were statistically significant $(p<0.05)$. The relative fresh weight was affected by salicylic acid treatments, since control cut flowers had significantly lower relative fresh weight during experiment, while the highest levels were obtained with 3 $\mathrm{mM}$ salicylic acid treatment (Fig. 1). Kazemi and Ameri (2012) showed that the treated cut gerbera flowers with salicylic acid had the highest levels of relative fresh weight during vase period. Also, the data indicates that among the presently tested treatments, pre + post-harvest application of salicylic acid is found to be more effective in increasing relative fresh weight of cut alstroemeria flowers during vase period than in the post-harvest application of salicylic acid (Fig. 1).

The decrease in relative fresh weight of cut flowers during the days of after harvest could be due to the decrease in water uptake (Bieleski and Reid, 1992; Serek et al., 1995). Alaey et al. (2011) reported that the highest relative fresh weight of cut rose flowers was observed in vase solutions which showed the greatest water uptake. In this experiment, all treatments showed decreases in relative fresh weight, although this decreases were significantly lower in treatments of salicylic acid than in the control treatment. This effect can be attributed to the acidifying and stress alleviating properties of salicylic acid, thereby enhancing 

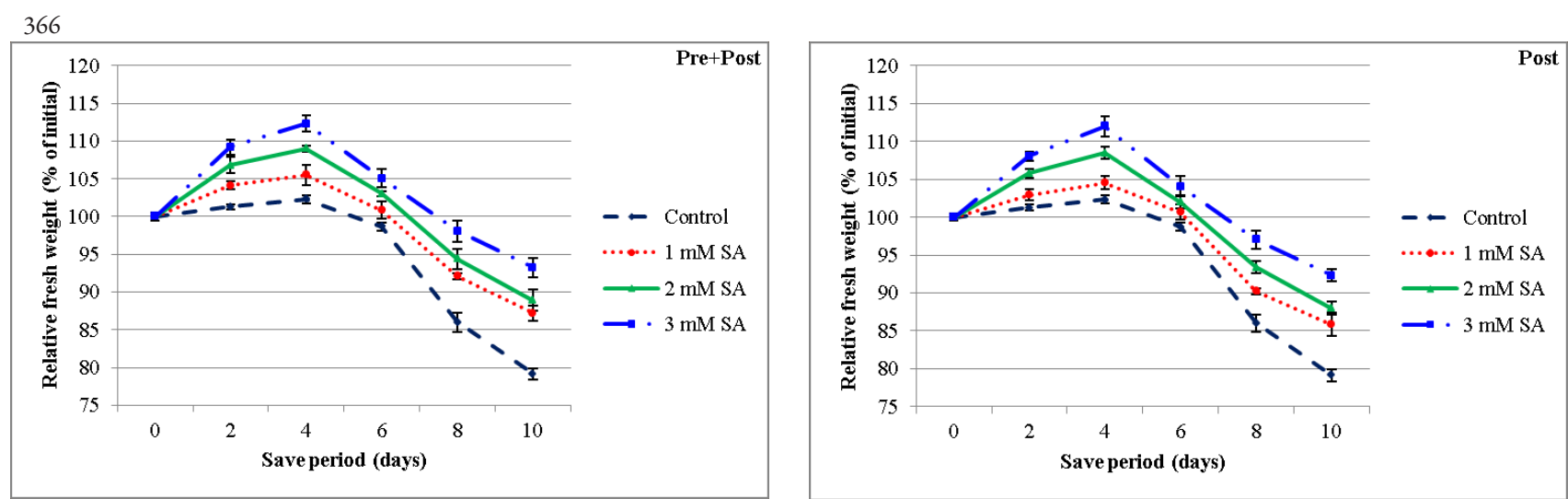

Fig. 1. Effect of pre + post-harvest and post-harvest applications of different concentrations of salicylic acid on relative fresh weight (\% of initial) of cut alstroemeria flowers during vase period. The results represent the means of 12 cut flowers in 4 replicates \pm standard errors

water uptake and relative fresh weight of cut flowers (Vahdati et al., 2012).

\section{Water uptake}

The results showed that the water uptake increased significantly during the first 4 days of after harvest and from this time until end of the experiment decreased significantly (Fig. 2). The results were in agreement with the findings reported by Lu et al. (2010) on cut rose flowers (cv. 'Movie Star'). Significant differences $(p<0.05)$ were revealed among the treatments for water uptake. The treatments of salicylic acid showed significantly highest water uptake than in the control treatment during experiment. The higher the salicylic acid concentration applied, the greater the improvement in water uptake, that highest water uptake values were observed in $3 \mathrm{mM}$ salicylic acid treatment (Fig. 2). Similar results were also reported for cut flowers of rose (Alaey et al., 2011; Zamani et al., 2011) gerbera (Kazemi et al., 2011 a). In relation to water uptake, pre + post-harvest salicylic acid application was more effective on increasing water uptake of cut alstroemeria flowers during experiment, as compared to application of post-harvest salicylic acid (Fig. 2).

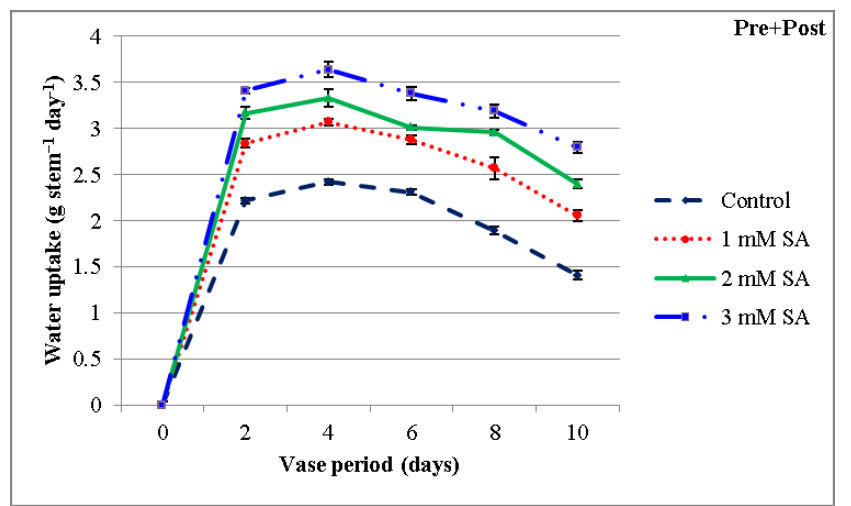

Previous study had revealed that the pathogens affect water uptake due to vascular blockage (Vahdati et al., 2012). The decrease in water uptake of cut flowers during vase period was probably due to growth of microbes and vascular blockage. Anjum et al. (2001) suggested adding a suitable germicide in vase solution can prevent the growth of microbes and increased water uptake. During vase period, the salicylic acid treatments maintained significantly a more favourable water uptake than in the control treatment. Salicylic acid can be decreased $\mathrm{pH}$ of vase solution and consequently, the growth and proliferation of bacteria was reduced, which led to increase water uptake (Raskin, 1992).

\section{Water loss}

The water loss increased significantly during experiment, that the water loss levels at the initial of the after harvest were higher than the end ones just (Fig. 3). Our results were in agreement is in agreement with $\mathrm{Lu}$ et al. (2010) who reported that the water loss of cut rose flowers increased significantly after harvest. As shown in Fig. 3 , a significant variation in water loss was found among the studied treatments. The lowest levels of water loss was observed for $3 \mathrm{mM}$ salicylic acid treatment during vase

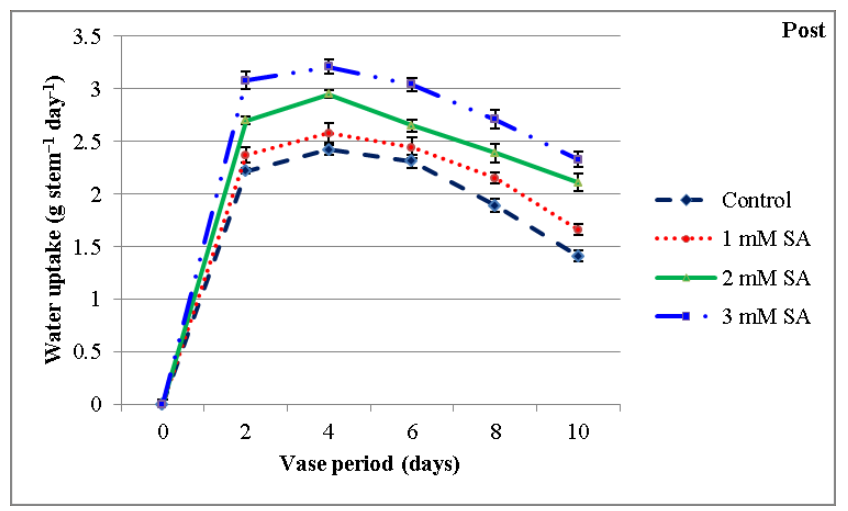

Fig. 2. Effect of pre + post-harvest and post-harvest applications of different concentrations of salicylic acid on water uptake (g stem $^{-1}$ day $^{-1}$ ) of cut alstroemeria flowers during vase period. The results represent the means of 12 cut flowers in 4 replicates \pm standard errors 

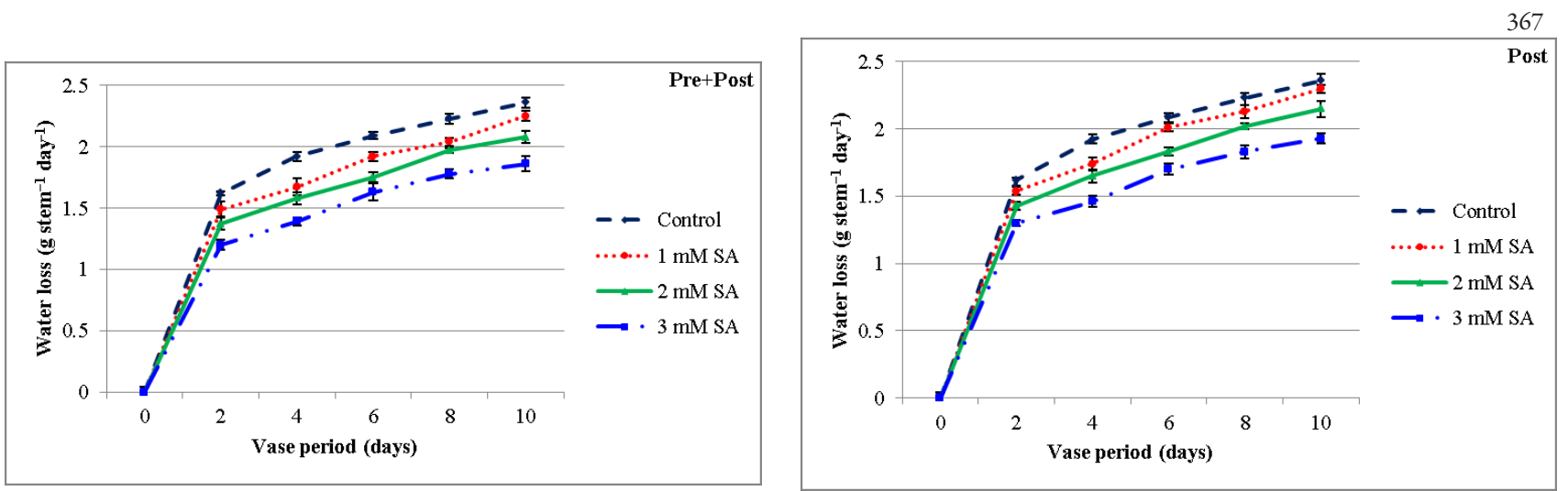

Fig. 3. Effect of pre + post-harvest and post-harvest applications of different concentrations of salicylic acid on water loss $\left(\mathrm{g}\right.$ stem ${ }^{-1}$ day $^{-1}$ ) of cut alstroemeria flowers during vase period. The results represent the means of 12 cut flowers in 4 replicates \pm standard errors

period, followed by $2 \mathrm{mM}$ and $1 \mathrm{mM}$ salicylic acid treatments while the highest was in control treatment. With respect to the results, the application of pre + post-harvest salicylic acid is found to be more effective than in the postharvest salicylic acid application in reducing water loss of cut alstroemeria flowers after harvest (Fig. 3).

According to Van Doorn (1997), water deficit in a cut stem standing in vase solution will develop when the rate of water uptake is lower than the rate of transpiration. In our experiment, salicylic acid treatments supressed significantly water loss than in the control treatment. It was assumed that the effect of salicylic acid treatment on lower of water loss could be due to the increasing water uptake (Raskin, 1992) as well as decrease in transpiration rate (Mei-hua et al., 2008).

\section{Water balance}

The results in this experiment showed that the water balance decreased significantly during experiment (Fig. 4). Reduction in the water balance during vase period is in agreement with Lu et al. (2010) who reported that the water balance of cut rose flowers declined almost linearly with vase time. There was a significant difference $(p<0.05)$ between control and salicylic acid treatments in terms of

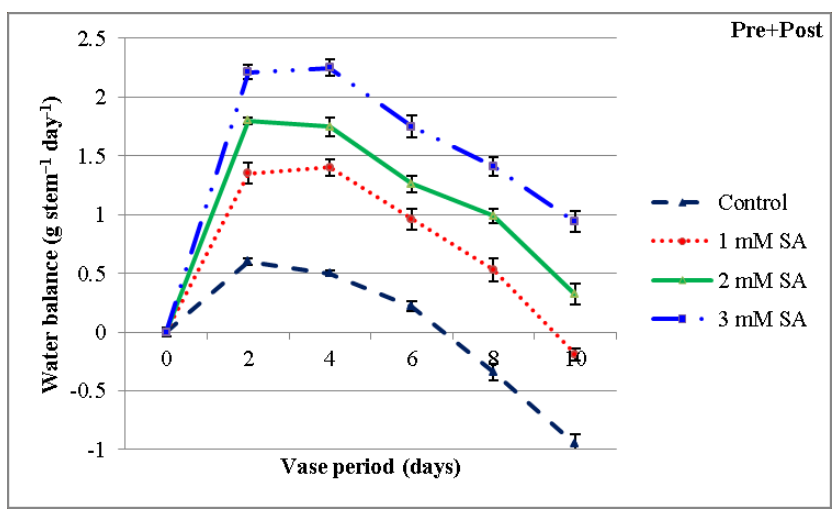

their effects on water balance levels. Among the studied treatments, $3 \mathrm{mM}$ salicylic acid treatment had the highest amount of water balance and control treatment had the lowest water balance content during experiment (Fig. 4). Also, the data indicated that the application of pre+ post-harvest salicylic acid was more effective than in the post-harvest salicylic acid application in change of water balance values during vase period (Fig. 4).

During vase period, the decrease in water balance of cut flowers in association with a lower water uptake and high water loss. In the current research, salicylic acid treatments maintained a more favourable water uptake and suppressed water loss than in the control treatment. This effect salicylic acid may be due to antimicrobial activity (inhibiting vascular blockage), increases the water uptake (Mori et al., 2001) and decrease in transpiration rate (Meihua $e t$ al., 2008), thereby enhancing water balance of cut flowers.

\section{Total chlorophyll}

According to results shown in Fig. 5, the total chlorophyll content decreased significantly during experiment, that the levels of total chlorophyll at the initial of the after harvest were higher than the end ones just. The results

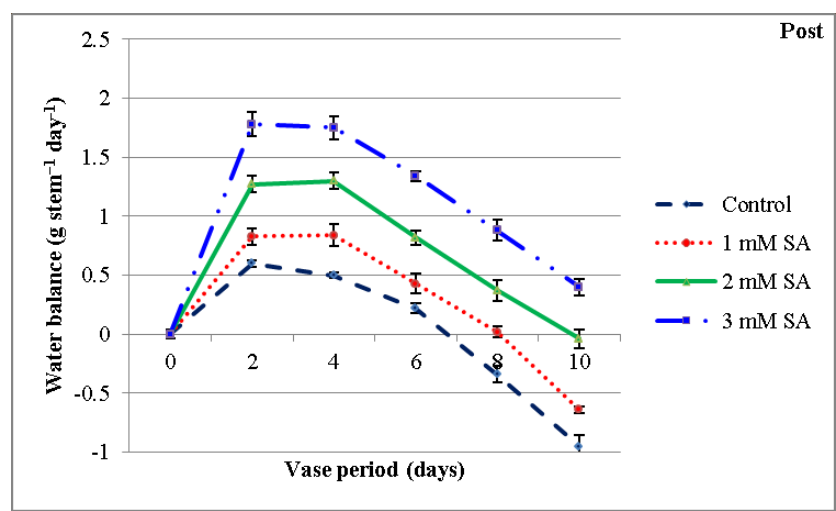

Fig. 4. Effect of pre + post-harvest and post-harvest applications of different concentrations of salicylic acid on water balance (g stem $^{-1}$ day $^{-1}$ ) of cut alstroemeria flowers during vase period. The results represent the means of 12 cut flowers in 4 replicates \pm standard errors 

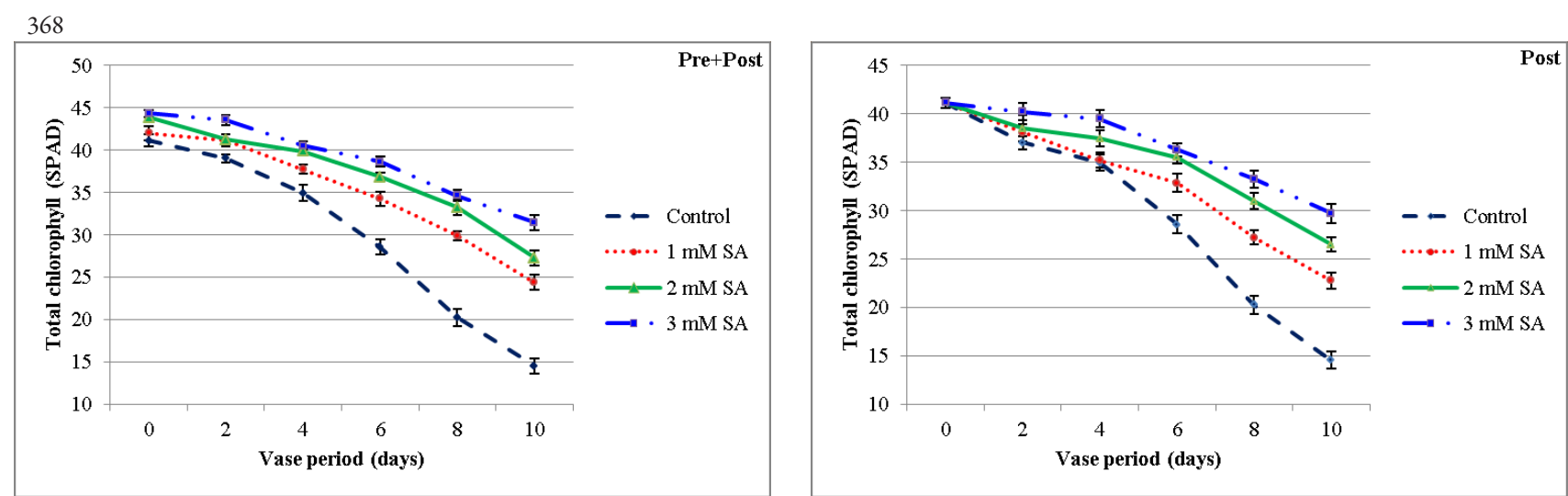

Fig. 5. Effect of pre + post-harvest and post-harvest applications of different concentrations of salicylic acid on total chlorophyll (SAPD) of cut alstroemeria flowers during vase period. The results represent the means of 12 cut flowers in 4 replicates \pm standard errors

were in agreement with the findings reported by Ferrante et al. (2002). There were significant differences in the total chlorophyll content of the different treatments. The lowest and highest the total chlorophyll values were observed in control and $3 \mathrm{mM}$ salicylic acid treatments, respectively (Fig. 5). Similar data were also reported for cut flowers of gerbera (Kazemi et al., 2011 a), lily (Kazemi et al., 2011 b) and rose (Zamani et al., 2011). The based on the present data, pre + post-harvest application of salicylic acid is found to be more effective in maintaining total chlorophyll values of cut alstroemeria flowers after harvest, as compared to application of post-harvest salicylic acid (Fig. 5).

The maintenance of green colour in the leaves is an important quality properties in these economically significant ornamental plants. Previous study had revealed that the leaf yellowing of cut alstroemeria flowers is associated with chlorophyll breakdown and loss, thereby decreasing significant vase life (Ferrante et al., 2002). According to Fig. 5, all treatments showed decreases in total chlorophyll content, although this decreases were significantly lower in treatments of salicylic acid than in the control treatment. Zamani et al. (2010) reported that the salicylic acid treatment reduced total chlorophyll degradation and preserved total chlorophyll content, is might be due to inhibiting ethylene action, as compared to control treatment.

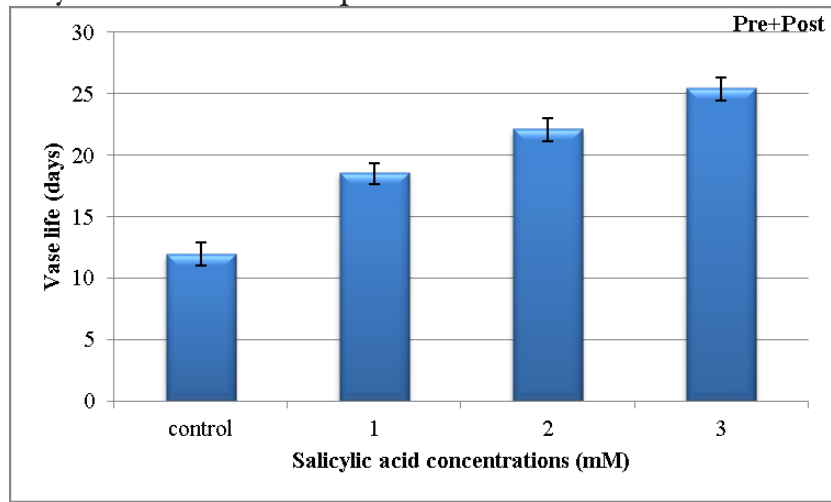

\section{Vase life}

The significant differences $(p<0.05)$ were revealed among the treatments for vase life, that the control treatment had the lowest vase life and $3 \mathrm{mM}$ salicylic acid treatment had the highest vase life after harvest (Fig. 6). With respect to the results, using salicylic acid treatment increased significantly the vase life cut alstroemeria flowers, as compared to control treatment during experiment. Previous researches had revealed that the salicylic acid treatments significantly extend the vase life of cut flowers (Mei-hua et al., 2008; Yuping, 2009; Kazemi et al., 2011a and b; Zamani et al., 2011; Vahdati et al., 2012), that is in agreement with our results. As shown in Fig. 6, application of pre + post-harvest salicylic acid is found to be more effective in extending vase life of cut alstroemeria flowers after harvest than in the post-harvest salicylic acid application.

The short vase life of cut flowers was caused by poor water relations in association with a lower water uptake (probably due to growth of microbes and vascular blockage), high rate of transpiration and water loss. The data indicated that the salicylic acid treatments increased significantly vase life of cut alstroemeria flowers than in the control treatment. This effect of salicylic acid is might be due to reduced the bacteria growth and vascular blockage, maintained a more favourable water uptake, suppressed

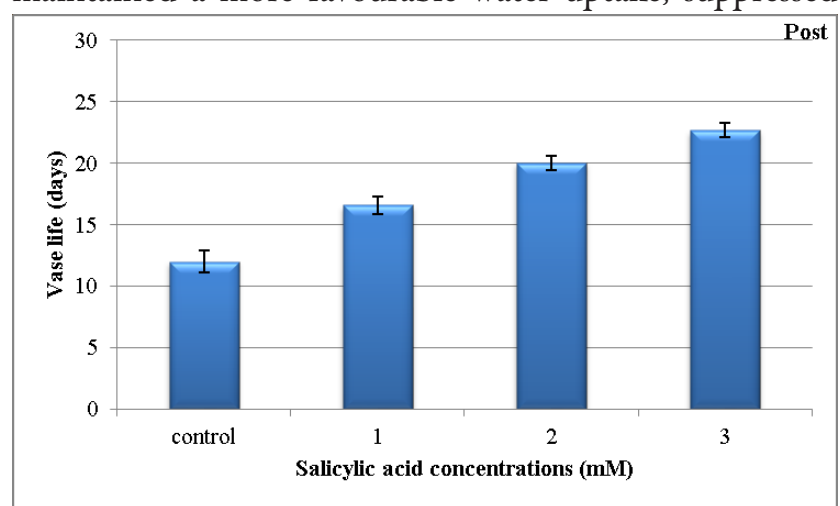

Fig. 6. Effect of pre + post-harvest and post-harvest applications of different concentrations of salicylic acid on vase life (days) of cut alstroemeria flowers in experiment. The results represent the means of 12 cut flowers in 4 replicates \pm standard errors 
water loss (Raskin, 1992; Mori et al., 2001), inhibiting ethylene action (Zamani et al., 2010) and decrease in transpiration rate (Mei-hua et al., 2008).

\section{Conclusions}

The naturally short vase life of the cut flowers is one of the most important problems. The using of different treatments is recommended to keeping quality and extending the vase life of cut flowers. In this study, influence of salicylic acid pre and post-harvest applications on keeping quality and vase life of cut alstroemeria flowers during vase period were investigated. This research showed that the same behaviour in all measured factors after harvest for all treatments. The relative fresh weight, water uptake, water balance, total chlorophyll content and vase life decreased significantly while water loss increased significantly during vase period. In addition, statistically significant differences were observed between control and salicylic acid treatments in all measured parameters. In terms of overall performance, application of pre + post-harvest salicylic acid is found to be more effective than in the post-harvest salicylic acid application. Exogenous salicylic acid treatment is able to increase vase life of cut alstroemeria flowers by regulating the plant water and increasing total chlorophyll content. Thus, the data suggest that salicylic acid treatment has the potential to be used commercially to extend the vase life of cut alstroemeria flowers.

\section{Acknowledgements}

The authors would like to acknowledge from Science and Research Branch, Islamic Azad University for its kind cooperation and their assistance in different aspects of this study.

\section{References}

Alaey M, Babalar M, Naderi R, Kafi M (2011). Effect of preand postharvest salicylic acid treatment on physio-chemical attributes in relation to vase-life of rose cut flowers. Postharvest Biol Technol 61:91-94.

Anjum MA, Naveed F, Shakeel F, Amin S (2001). Effect of some chemicals on keeping quality and vase life of tuberose ( $P O-$ lianthus tuberosa L.) cut flower. J Res Sci 21:1-7.

Ansari MS, Misra N (2007). Miraculous role of salicylic acid in plant and animal system. Am J Plant Physiol 2:51-58.

Bieleski RL, Reid MS (1992). Physiological changes accompanying senescence in the ephemeral daylily flower. Plant Physiol 98:1042-1049.

Canakci S (2008). Effects of salicylic acid on fresh weight change, chlorophyll and protein amounts of radish (Raphanus sativus L.) seedling. J Biol Sci 8:431-435.

Da Silva JAT (2003). The cut flower: postharvest considerations. J Biol Sci 3:406-442.

Ferrante A, Hunter DA, Hackett WP, Reid MS (2002). Thidi- azuron a potent inhibitor of leaf senescence in alstroemeria. Postharvest Biol Technol 25:333-338.

Hayat Q, Hayat S, Irfan M, Ahmad A (2010). Effect of exogenous salicylic acid under changing environment: a review. Enviro Exp Bot 68:14-25.

He S, Joyce DC, Irving DE, Faragher JD (2006). Stem end blockage in cut grevillea 'Crimson Yul-lo' inflorescences. Postharvest Biol Technol 41:78-84.

Hicklenton PR (1991). GA 3 and benzylaminopurine delay leaf yellowing in cut alstromeria stems. Hort Sci 26:1198-1199.

Jordi W, Stoopen GM, Kelepouris K, Krieken WM (1995). Gibberellin-induced delay of leaf senescence of alstroemeria cut flowering stems is not caused by an increase in the endogenous cytokinin content. J Plant Growth Regulat 14:121-127.

Kalidage H, Yildirm E, Turan M (2009). Salicylic acid ameliorates the adverse effect of salt stress on strawberry. Sci Agric (Piracicaba, Braz) 66:180-187.

Kazemi M, Ameri A (2012). Response of vase-life carnation cut flower to salicylic acid, silver nanoparticles, glutamine and essential oil. Asian J Animal Sci 6(3):122-131.

Kazemi M, Zamani S, Aran M (2011a). Effect of some treatment chemicals on keeping quality and vase-life gerbera cut flowers. Am J Plant Physiol 6(2):99-105.

Kazemi M, Zamani S, Aran M (2011b). Interaction between glutamin and different chemicals on extending the vase life of cut flowers of 'Prato' lily. Am J Plant physiol 6:120-125.

Lu P, Cao J, He S, Liu J, Li H, Cheng G, Ding Y, Joyce DC (2010). Nano-silver pulse treatments improve water relations of cut rose cv. 'Movie' Star flowers. Postharvest Biol Technol 57:196-202.

Luo Z, Chen C, Xie J (2011). Effect of salicylic acid treatment on alleviating postharvest chilling injury of 'Qingnai' plum fruit. Postharvest Biol Technol 62:115-120.

Mahdavian K,. Kalantari KM, Ghorbanli M (2007). The effect of different concentrations of salicylic acid on protective enzyme activites of pepper (Capsicum annuum L.) plants. Pak J Biol Sci 10:3162-3165.

Mba FO, Zhi-Ting X, Hai-Jie Q (2007). Salicylic acid alleviates the cadmium toxicity in chinese cabbage (Brassica chinensis). Pak J Biol Sci 10:3065-3071.

Mei-hua F, Jian-xin W, Shi L, Shi G, Fan L (2008). Salicylic acid and 6-BA effects in shelf-life improvement of Gerbera Jamesonii cut flowers. Anhui Agricultural Science Bulletin. http://en.cnki.com.cn/Article-en/CJFDTOTALBFYY200808060.htm.

Mori IC, Pinontoan R, Kawano T, Muto S (2001). Involvement of superoxide generation in salicylic acid-induced stomatal closure in vicia faba. Plant Cell Physiol 42:1383-1388.

Mutui TM, Emongor VE, Hutchinson MJ (2001). Effect of accel on the vase life and postharvest quality of alstroemeria (Alstroemeria aurantiaca L.) cut flowers. African J Sci Technol 2(1):82-88. 
370

Mutui TM, Emongor VE, Hutchinson MJ (2003). Effect of benzyladenine on the vase life and keeping quality of alstroemeria cut flowers. J Agric Sci Technol 5:91-105.

Norbaek R, Christensen LP, Bojesen G, Brandt K (1996). Anthocyanins in chilean species of alestroemeria. Phytochem 42(1):97-100.

Nowak J, Rudnicki RM (1990). Postharvest handling and storage of cut flowers, florist greens, and potted plants. Timber Press.

Raskin I (1992). Role of salicylic acid in plants. Annu Rev Plant Physiol Plant Mol Biol 43:439-463.

Sankat CK, Mujaffar S (1994). Water balance in cut anthurium flowers in storage and its effect on quality. Acta Hort 368:723-732.

Serek M, Tamari G, Sisler EC, Borochov A (1995). Inhibition of ethylene-induced cellular senescence symptoms by 1-methylcyclopropene, a new inhibitor of ethylene action. Physiol Plant 94:229-232.
Vahdati NM, Tehranifar A, Bayat H, Selahvarzi Y (2012). Salicylic and citric acid treatments improve the vase life of cut chrysanthemum flowers. J Agric Sci Technol 14:879-887.

Van Doorn WG (1997). Water relations of cut flowers. Hort Rev 18:1-85.

Witte Y, Van Doom (1991). The mode of action of bacteria in the vascular occlusion of cut rose flowers. Acta Hort 298:165-167.

Wu MJ, Zacarias L, Reid MS (1991). Variation in the senescence of carnation (Dianthus caryophyllus L.) cultivars. II. Comparison of sensitivity to exogenous ethylene and of ethylene binding. Sci Hort 49:109-116.

Yuping Z (2009). Effects of salicylic acid on fresh keeping of cut Gerbera jamesonii flower. Anhui Agricultural Science Bulletin.

Zamani S, Kazemi M, Aran M (2011). Postharvest life of cut rose flowers as affected by salicylic acid and glutamin. World Appl Sci J 12(9):1621-1624. 